\title{
The Determination of Monthly Premium of Joint Term Health Insurance for Hospital Care
}

\author{
Darma Ekawati \\ ${ }^{1}$ Mathematics, Universitas Sulawesi Barat, Indonesia, e-mail : darmaekawati@unsulbar.ac.id
}

\begin{tabular}{|c|}
\hline Article history: \\
\hline Received : 22-08-2020 \\
\hline Revised : 08-09-2020 \\
\hline Accepted : 11-09-2020 \\
\hline $\begin{array}{l}\text { Keyword: } \\
\text { Hospital; } \\
\text { Health Insurance; } \\
\text { Premiums; } \\
\text { Medicine; } \\
\text { Joint Term Insurance }\end{array}$ \\
\hline 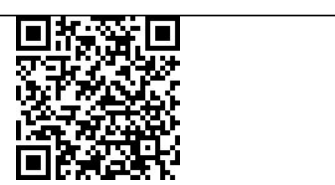 \\
\hline
\end{tabular}

\begin{abstract}
Hospital care is one of the insurance products giving compensation to the members by reimbursing the medicine and hospital care costs. According to the number of members in one insurance policy, health insurance is classified into two categories namely individual health insurance and joint health insurance. This article discusses the monthly premium of joint health insurance. The monthly premium of joint term health insurance is calculated before deciding the probability to facilitate hospital care for two or more people using The RP-2000 Combined Healthy Tables and joint life annuity. Based on the simulation, at the same benefit, the monthly premium that must be paid for joint health insurance is smaller than for individual health insurance because the premium for joint insurance are borne by some insured under the same insurance policy
\end{abstract}

This is an open access article under the CC BY-SA license.

DOI: https://doi.org/10.30812/varian.v4i1.844

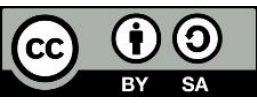

\section{A. INTRODUCTION}

Each human will obviously face risks in their life. A risk is the uncertainty of an event that possibly brings disadvantages. Risks faced by each person are various. One of them is the attack of disease and no one knows when they will experience it. Once it happens, they must solve it by finding out medication so that they can go back to their normal daily routines.

Health insurance is a facility to minimize or to solve the risk of sickness and costs it results. Based on the insurance contract, members have to pay a particular amount of money or premium every period to the insurance company. In return, they will get a benefit in the form of compensation to subsidize or to reimburse the whole cost spent for health care when getting ill.

Health insurance is a part of life insurance with life as an object. The purpose of health insurance is to transfer the risk of illness from the insured to the insurer. Thus, the insurer has the responsibility to provide (cost of) healthcare service to the insured when sick. It is to protect the community from (economic) difficulties to pay the health care costs (Suryono, 2009).

Health insurance has some types. Based on the kinds of treatment, it is divided into two categories, inpatient health insurance, and outpatient health insurance. While according to the number of members in one insurance policy, it is categorized into individual and joint health insurance. 
Health insurance for hospital care provides compensation for health by giving a particular amount of money to pay medicine and other health care when somebody is sick (Wilandari, 2007). Joint health insurance bears 2 or more persons (Gunanto, Hasriati, \& Pane, 2014).

Studies related to health insurance for hospital care have been widely carried out including investigating the individual health insurance premium for hospital care (Wilandari, 2007), cost-sharing machanisms in health insurance schemes (Qingyue, Liying, \& Beibei, 2011) and public and private health insuranse premiums (Guy, Adams, \& Atherly, 2012) . It was followed up about studying the formulation of monthly individual health insurance for hospital care (Lahallo, Widana, \& Nilakusmawati, 2013), the effect of change in interest rate on the calculation of annual premium individual health insurance (Pradipta, Widana, \& Sugiarto, 2013), comparison of the health insurance premiums of business entity BPJS participants with private health insurance (Dewi \& Sulistyani, 2015). While related to joint health insurance, studied about its purpose for hospital care (Munadi \& Sunarsih, 2009), the annual premium reserves for joint health insurance (Gunanto et al., 2014), research that discusses the determination of individual and annual health insurance premiums under individual and joint status (Hayuningtias, Ruswandi, Warsono, \& Nusyirwan, 2019).

This study basically aimed at continuing the study about the determination of monthly premium for hospital care of individual term health insurance (Espinoza, 2016), while the current research investigated that of joint term health insurance. The purpose of this study was to compare the monthly premium that must be paid by each family member as a member of individual health insurance and the premium they must pay for joint status.

\section{B. LITERATURE REVIEW}

\section{Life Annuities with $m$-thly Payments}

An annuity is a payment series with a particular amount of money paid every an interval and during a period (Juliandi, Satyahadewi, \& Mara, 2015). It is an important component in calculating the insurance premium. One of the annuity systems mostly applied by a life annuity is that the payment depends on the life and death of a person (Juliandi et al., 2015). The life annuity is paid once in a year, at the beginning of the year by a person aged $\mathrm{X}$ during $\mathrm{n}$ years. It is also usually referred to as annuity calculated using the following formula (1) (Bowers, Gerber, \& Hickman, 1997):

$$
\ddot{a}_{x: \bar{n} \mid}=\sum_{t=0}^{n-1} v^{t}{ }_{t} p_{x}
$$

$v=\frac{1}{1+i}, i$ is the annual interest rate, and ${ }_{t} p_{x}$ the probability of a person aged $x$ will attain ages $x+t$.

Based on the annuity formula above, another equation to calculate the annuity with $m$ - thly payment in a year can be derived (Juliandi et al., 2015):

$$
\ddot{a}_{x: \bar{n} \mid}^{(m)}=\frac{t}{m} \sum_{t=0}^{(n m)-1} v^{\frac{t}{m}} \frac{t}{m} p_{x}
$$

Using the commutation symbol, equation (2) can be presented as below (Espinoza, 2016):

$$
\ddot{a}_{x: \bar{n} \mid}^{(m)}=\frac{N_{x}-N_{x+n}}{D_{x}}-\frac{m-1}{2 m}\left(1-\frac{D_{x+n}}{D_{x}}\right)
$$

If the annuity payment is made every month or 12 times in a year, the amount of the monthly annuity for $n$ years is:

$$
\ddot{a}_{x: \bar{n} \mid}^{(12)}=\frac{N_{x}-N_{x+n}}{D_{x}}-\frac{11}{24}\left(1-\frac{D_{x+n}}{D_{x}}\right)
$$

\section{Monthly Premium of Health Insurance}

The insurance premium is the payment that must be made by insurance members (insured) to the insurance party (insurer) under the coverage agreement signed on the insurance contract letter. Based on payment time, the premium can be paid once (single premium) or periodically (annual or monthly premium). The single premium of term health insurance for hospital care for individual member aged $x$, with $T^{s h}$ the average days staying in the hospital and $q_{x}^{s h}$ the probability of a person 
aged $x$ to be hospitalized during $n$ years of coverage can be calculated using the following formula (Wilandari, 2007):

$$
P_{x: \bar{n} \mid}^{1}=T^{s h} \sum_{t=0}^{n-1} v^{t+\frac{1}{2}} i_{t} p_{x} \quad q_{x+t}^{s h}
$$

Using the commutation symbol, we obtain (Espinoza, 2016)

$$
P_{x: \bar{n} \mid}^{1}=\frac{1}{D_{x}} T^{s h} \sum_{t=0}^{n-1} \bar{D}_{x+t} q_{x+t}^{s h}
$$

The monthly premium is paid at the beginning of each month by an insurance member during $n$ years. The calculation of monthly premium during $n$ years of the term insurance contract is based on the term annuity of $n$ years paid 12 times in a year.

The amount of health insurance premium with the term of $n$ years for hospital care that must be paid by an insurance member aged $x$ when the insurance contract is signed or the benefit of $B$ is formulated (7):

\section{Commutation Symbol}

$$
P_{x: \bar{n} \mid}^{1(12)}=B \frac{P_{x: \bar{n} \mid}^{1}}{12 \ddot{a}_{x: \bar{n} \mid}^{(12)}}=B \frac{T^{s h} \sum_{t=0}^{n-1} \bar{D}_{x+t} q_{x+t}^{s h}}{12\left(N_{x}-N_{x+n}-\frac{11}{24}\left(D_{x}-D_{x+n}\right)\right)}
$$

The symbol of commutation is made to assist the calculation of insurance value like an annuity, and premium (Sari \& Jazwinarti, 2016).

Symbols of commutation in joint insurance covering $m$ persons are defined analogously with the commutation symbol of individual insurance (Sari \& Jazwinarti, 2016), as formula (8) and (9):

and

$$
D_{x_{1}, x_{2}, x_{3}, \ldots x_{m}}=v^{\frac{x_{1}, x_{2}, x_{3}, \ldots x_{m}}{m}} l_{x_{1}, x_{2}, x_{3}, \ldots x_{m}}
$$

$$
N_{x_{1}, x_{2}, x_{3}, \ldots x_{m}}=\sum_{i=0} D_{x_{1}+i ; x_{2}+i ; x_{3}+i ; \ldots ; x_{m}+i}
$$

\section{RESEARCH METHOD}

This is a literature review started by collecting materials from various supporting resources, formulating problems, and establishing steps and formula to determine the monthly premium of joint term health insurance for hospital care. The last step was to use the equation into a relevant case illustration or simulation.

\section{RESULTS AND DISCUSSION}

\section{Joint Mortality Tables}

Similarly, with a single mortality table, that table for joint mortality presents the death rate to determine the insurance premium (Futami, 1993). In the joint mortality table of some persons aged $x_{1}, x_{2}, x_{3}, \ldots x_{m},\left(x_{1}, x_{2}, x_{3}, x_{4} \ldots x_{m}\right.$ are independent), the function of the number of people aged $x_{1}$ is multiplied with the function of the number of people aged $x_{2}, x_{3}, \ldots x_{m}$ years notated with $l_{x_{1}, x_{2}, x_{3}, \ldots x_{m}}$ is formulated (10) and (11):

$$
l_{x_{1}, x_{2}, x_{3}, \ldots x_{m}}=l_{x_{1}} \cdot l_{x_{2}} \ldots l_{x_{m}}
$$

The probability of persons aged $x_{1}, x_{2}, x_{3}, \ldots x_{m}$ years to stay alive until 1 year later is:

$$
p_{x_{1}, x_{2}, x_{3}, \ldots x_{m}}=p_{x_{1}} \cdot p_{x_{2}} \ldots p_{x_{m}}
$$

\section{Monthly Premium of Term Joint Health Insurance for Hospital Care}

Joint health insurance covers 2 or more people. The calculation of life annuity of joint health insurance is analogous with individual health insurance. Based on equation (6), the single premium of joint health insurance covering $m$ members aged $x_{1}, x_{2}, x_{3}, \ldots$, and $x_{m}$ can be equated formulate (12):

$$
P_{x_{1}, x_{2}, x_{3}, \ldots x_{m}: \bar{n} \mid}^{1}=\frac{1}{D_{x_{1}, x_{2}, x_{3}, \ldots . x_{m}}} T^{s h} \sum_{t=0}^{n-1} \bar{D}_{x_{1}+t ; x_{2}+t ; \ldots ; x_{m}+t} q_{x_{1}+t ; x_{2}+t ; x_{3}+t ; \ldots ; x_{m}+t}^{s h}
$$

and based on equation (4) the term annuity of joint insurance covering more than two persons aged $x_{1}, x_{2}, x_{3}, \ldots$ and $x_{m}$ years paid at the beginning of each month for $n$ years is: 


$$
\ddot{a}_{x_{1}, x_{2}, x_{3}, \ldots x_{m}: \bar{n} \mid}^{(12)}=\frac{N_{x_{1}, x_{2}, x_{3}, \ldots x_{m}}-N_{x_{1}+n ; x_{2}+n ; x_{3}+n ; \ldots ; x_{m}+n}}{D_{x_{1}, x_{2}, x_{3}, \ldots x_{m}}}-\frac{11}{24}\left(1-\frac{D_{x_{1}+n ; x_{2}+n ; x_{3}+n ; \ldots ; x_{m}+n}}{D_{x_{1}, x_{2}, x_{3}, \ldots, x_{m}}}\right)
$$

thus, the premium rate of terms joint health insurance of $n$ years for hospital care that must be paid by the members with benefit $B$ is formulated (14):

$$
P_{x_{1}, x_{2}, \ldots . \ldots x_{m}: \bar{n} \mid}^{1(12)}=\frac{P_{x_{1}, x_{2}, \ldots x_{m}: \bar{n} \mid}^{1}}{\ddot{a}_{x_{1}, x_{2}, \ldots x_{m}: n \bar{n}}^{(12)}}=B \frac{T^{s h} \sum_{t=0}^{n-1} \bar{D}_{x_{1}+t ; x_{2}+t ; \ldots ; x_{m}+t} q_{x_{1}+t ; x_{2}+t ; \ldots ; x_{m}+t}^{s h}}{12\left(N_{x_{1}, x_{2}, \ldots . . x_{m}}-N_{x_{1}+t ; x_{2}+t ; \ldots ; x_{m}+t}-\frac{11}{24}\left(D_{x_{1}, x_{2}, \ldots x_{m}}-D_{x_{1}+t ; x_{2}+t ; \ldots ; x_{m}+t}\right)\right)}
$$

\section{Case Simulation}

There are two families and each of them has 5 members. The first family consists of an old man aged 60, an old woman aged 58, a middle-age man aged 35, a middle-aged woman aged 32, and a boy aged 7. The second family consists of a middle-age man aged 45, a middle-aged woman aged 40, a teenager aged 17, and two boys aged 15 and 10. Both families apply for the health insurance policy for hospital care for

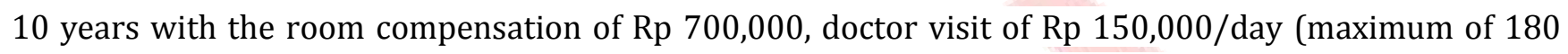
days in a year), and care cost per period per year of Rp 5,000,000. Based on the Indonesian Mortality Table 2011, RP-2000 Combined healthy table, and the interest rate of $6 \%$, we obtained the data Table 1,2 and 3:

1) Individual health insurance

Based on the available data, it is obtained that the premium must be paid by each health insurance participant presented in the following Table 1:

\begin{tabular}{|c|c|c|}
\hline \multirow{2}{*}{ Family members } & \multicolumn{2}{|c|}{ Individual Monthly Premium } \\
\hline & The $1^{\text {st }}$ family & The $2^{\text {nd }}$ family \\
\hline I & Rp 113.788 & $\mathrm{Rp} 31.713$ \\
\hline II & Rp 70.670 & Rp 15.796 \\
\hline III & Rp 15.519 & $\mathrm{Rp} 2.925$ \\
\hline IV & Rp 7.869 & Rp 4.901 \\
\hline $\mathrm{V}$ & Rp $\quad 3.510$ & $\begin{array}{ll}\mathrm{Rp} & 3.894 \\
\end{array}$ \\
\hline Total of premium & Rp 211.356 & Rp 59.229 \\
\hline
\end{tabular}

Table 1. The Monthly Premium of Health Insurance for Hospital Care for 10 Years of Each Member

2) Joint health insurance

Based on the available data, a table containing the data of combined healthy and commutation of the first family under a joint insurance is as Table 2:

Table 2. Combined Healthy and Commutation of the First Family under a Joint Insurance

\begin{tabular}{ccccccccc}
\hline $\boldsymbol{x}_{\mathbf{1}}$ & $\boldsymbol{x}_{\mathbf{2}}$ & $\boldsymbol{x}_{\mathbf{3}}$ & $\boldsymbol{x}_{\mathbf{4}}$ & $\boldsymbol{x}_{\mathbf{5}}$ & $\boldsymbol{l}_{\boldsymbol{x}_{\mathbf{1}}, \ldots \boldsymbol{x}_{\mathbf{5}}}$ & $\boldsymbol{D}_{\boldsymbol{x}_{\mathbf{1}}, \ldots \boldsymbol{x}_{\mathbf{5}}}$ & $\overline{\boldsymbol{D}}_{\boldsymbol{x}_{\mathbf{1}}, \ldots \boldsymbol{x}_{\mathbf{5}}}$ & $\boldsymbol{q}_{\boldsymbol{x}_{\mathbf{1}}, \ldots \boldsymbol{x}_{\mathbf{5}}}$ \\
\hline 60 & 58 & 35 & 32 & 7 & $7,51005 \times 10^{24}$ & $7,73952 \times 10^{23}$ & $7,30143 \times 10^{23}$ & 0,009934 \\
\hline 61 & 59 & 36 & 33 & 8 & $7,33281 \times 10^{24}$ & $7,12912 \times 10^{23}$ & $6,72559 \times 10^{23}$ & 0,010883 \\
\hline 62 & 60 & 37 & 34 & 9 & $7,14804 \times 10^{24}$ & $6,55611 \times 10^{23}$ & $6,18501 \times 10^{23}$ & 0,011893 \\
\hline 63 & 61 & 38 & 35 & 10 & $6,95522 \times 10^{24}$ & $6,01817 \times 10^{23}$ & $5,67752 \times 10^{23}$ & 0,012950 \\
\hline 64 & 62 & 39 & 36 & 11 & $6,75348 \times 10^{24}$ & $5,51284 \times 10^{23}$ & $5,20079 \times 10^{23}$ & 0,014026 \\
\hline 65 & 63 & 40 & 37 & 12 & $6,54145 \times 10^{24}$ & $5,03751 \times 10^{23}$ & $4,75237 \times 10^{23}$ & 0,015107 \\
\hline 66 & 64 & 41 & 38 & 13 & $6,31673 \times 10^{24}$ & $4,58911 \times 10^{23}$ & $4,32935 \times 10^{23}$ & 0,016186 \\
\hline 67 & 65 & 42 & 39 & 14 & $6,07936 \times 10^{24}$ & $4,16666 \times 10^{23}$ & $3,93081 \times 10^{23}$ & 0,017256 \\
\hline 69 & 66 & 43 & 40 & 15 & $5,83004 \times 10^{24}$ & $3,7696 \times 10^{23}$ & $3,55623 \times 10^{23}$ & 0,018309 \\
\hline
\end{tabular}

and a table containing the data of combined healthy and commutation of the second family under a joint insurance is Table 3 : 
Table 3. Combined Healthy and Commutation of the secondf family under a Joint Insurance

\begin{tabular}{ccccccccc}
\hline $\boldsymbol{x}_{\mathbf{1}}$ & $\boldsymbol{x}_{\mathbf{2}}$ & $\boldsymbol{x}_{\mathbf{3}}$ & $\boldsymbol{x}_{\boldsymbol{4}}$ & $\boldsymbol{x}_{\mathbf{5}}$ & $\boldsymbol{l}_{\boldsymbol{x}_{\mathbf{1}}, \ldots \boldsymbol{x}_{\mathbf{5}}}$ & $\boldsymbol{D}_{\boldsymbol{x}_{1}, \ldots \boldsymbol{x}_{\mathbf{5}}}$ & $\overline{\boldsymbol{D}}_{\boldsymbol{x}_{1}, \ldots \boldsymbol{x}_{\mathbf{5}}}$ & $\boldsymbol{q}_{\boldsymbol{x}_{1}, \ldots \boldsymbol{x}_{\mathbf{5}}}$ \\
\hline 45 & 40 & 17 & 15 & 10 & $9,08176 \times 10^{24}$ & $2,06729 \times 10^{24}$ & $1,95027 \times 10^{24}$ & 0,002879 \\
\hline 46 & 41 & 18 & 16 & 11 & $9,03886 \times 10^{24}$ & $1,94106 \times 10^{24}$ & $1,83119 \times 10^{24}$ & 0,003094 \\
\hline 47 & 42 & 19 & 17 & 12 & $8,99157 \times 10^{24}$ & $1,82161 \times 10^{24}$ & $1,7185 \times 10^{24}$ & 0,003333 \\
\hline 48 & 43 & 20 & 18 & 13 & $8,93896 \times 10^{24}$ & $1,70844 \times 10^{24}$ & $1,61174 \times 10^{24}$ & 0,003589 \\
\hline 49 & 44 & 21 & 19 & 14 & $8,88007 \times 10^{24}$ & $1,60112 \times 10^{24}$ & $1,51049 \times 10^{24}$ & 0,003866 \\
\hline 50 & 45 & 22 & 20 & 15 & $8,81422 \times 10^{24}$ & $1,49929 \times 10^{24}$ & $1,41442 \times 10^{24}$ & 0,004157 \\
\hline 51 & 46 & 23 & 21 & 16 & $8,74017 \times 10^{24}$ & $1,40254 \times 10^{24}$ & $1,32315 \times 10^{24}$ & 0,004462 \\
\hline 52 & 47 & 24 & 22 & 17 & $8,65692 \times 10^{24}$ & $1,31055 \times 10^{24}$ & $1,23637 \times 10^{24}$ & 0,004783 \\
\hline 53 & 48 & 25 & 23 & 18 & $8,56386 \times 10^{24}$ & $1,22308 \times 10^{24}$ & $1,15385 \times 10^{24}$ & 0,005125 \\
\hline 54 & 49 & 26 & 24 & 19 & $8,46082 \times 10^{24}$ & $1,13996 \times 10^{24}$ & $1,07544 \times 10^{24}$ & 0,005494 \\
\hline
\end{tabular}

Values in tables 2 and 3 are substituted into equation (14) and the monthly premiums of joint health insurances were obtained. The first family has to pay Rp 204,709 and the second family pays Rp 57,502

Based on the case simulation above, it can be seen that if those families apply for the individual health insurance policy for hospital care, the total monthly premiums they must pay are Rp 211.356 for the first family and 59.229 for the second family. Those amounts are higher than the monthly premiums for joint insurance that are Rp 204.709 for the first family and Rp 57.502 for the second family.

The monthly premium paid for joint health insurance is lower than for individual health insurance because the premium for joint insurance are borne by some insured under the same insurance policy so that the premium will be smaller. In the above cases, although both families consist of the same number of members, the first family will pay higher than the second family when they apply for individual or joint insurance because the first family has 2 elderlies. The probability of elder persons attacked with an illness and requiring hospital care is higher than middle-aged persons, teenagers, or children.

The previous research finding was only to calculate the monthly premium of health insurance that must be paid by one person, while the result of the current study can be applied for the joint insurance premium covering 2 or more members.

\section{E. CONCLUSION AND SUGGESTION}

The amount of monthly premium of $n$ year joint term health insurance for hospital care is influenced by the amount of compensation provided by the insurance company, the average number of days of hospital care, and the probability of people aged $x_{1}, x_{2}, x_{3}, \ldots$, and $x_{m}$ years in a particular period to be hospitalized. The monthly premium that must be paid for joint health insurance is smaller than for individual health insurance because the premium for joint insurance are borne by some insured under the same insurance policy. In both individual and joint health insurance with the same number of family members, the first family pays a higher premium than the second family because the first one has two elderly persons. The probabilities of elderlies to be attacked with illness and to require hospital care is higher than middle-age persons or children.

\section{ACKNOWLEDGEMENTS}

Researchers would like to thank the Universitas Sulawesi Barat for giving permission to collaborate in the field of research and provide moral support, so that this research can be carried out well.

\section{REFERENCES}

Bowers, N. L., Gerber, H. U., \& Hickman, J. C. (1997). Actuarial Mathematics. 2nd ed. Schaumburg: The Society of Actuaries.

Dewi, M. W., \& Sulistyani, D. (2015). Perbandingan Premi Asuransi Kesehatan Peserta Bpjs Badan Usaha Dengan Asuransi Kesehatan Swasta. Jurnal Akuntansi Dan Pajak, 16(01), 33-47.

Espinoza, E. (2016). Penentuan Premi Bulanan Asuransi Kesehatan Berjangka Perawatan Rumah Sakit Untuk Perorangan. Jurnal Matematika Unand, 5(4), 30-35.

Futami, T. (1993). Matematika Asuransi Jiwa Bagian I. Tokyo: Oriental Life Insurance Cultural Development Center. 
Gunanto, A., Hasriati, \& Pane, R. (2014). Cadangan Premi Tahunan Asuransi Kesehatan pada Status Gabungan. JOM 
31 | Jurnal Varian| Vol. 4, No. 1, Oktober 2020, Hal. 25-30

FMIPA, 1(2), 475-483.

Guy, G. P., Adams, E. K., \& Atherly, A. (2012). Public and Private Health Insurance Premiums: How Do They Affect the Health Insurance Status of Low-Income Childless Adults? Inquiry: The Journal of Health Care Organization, Provision, and Financing, 49(1), 52-64.

Hayuningtias, M., Ruswandi, R., Warsono, W., \& Nusyirwan, N. (2019). Menentukan Premi Asuransi Kesehatan untuk Perawatan Rumah Sakit pada Status Perorangan dan Joint Life. Seminar Nasional SMIAP V 2019.

Juliandi, Satyahadewi, N., \& Mara, M. N. (2015). Penentuan Nilai Anuitas Berjangka Individu dengan Metode Woolhouse. Buletin Ilmiah Mat. Stat. Dan Terapannya (Bimaster), 4(3), 259-268.

Lahallo, A. P. T. P., Widana, I. N., \& Nilakusmawati, D. P. E. (2013). Perumusan Premi Bulanan Asuransi Kesehatan Individu Perawatan Rumah Sakit (Anuitas Hidup Pembayaran Bulanan). E-Jurnal Matematika, 2(4), 40-45.

Munadi, \& Sunarsih. (2009). Asuransi Kesehatan Kumpulan untuk Perawatan Rumah Sakit. Jurnal Matematika, 12(2), 61-69.

Pradipta, Y., Widana, I. N., \& Sugiarto, Y. B. (2013). Pengaruh Perubahan Suku Bunga Terhadap Perhitungan Premi Neto Tahunan Asuransi Kesehatan Individu. E-Jurnal Matematika, 2(3), 17-22.

Qingyue, M., Liying, J., \& Beibei, Y. (2011). Cost-sharing Mechanisms in Health Insurance Schemes : A systematic Review. The Alliance for Health Policy and Systems Research, WHO, 1-76.

Sari, D. P., \& Jazwinarti. (2016). Anuitas Last Survivor untuk Kasus Tiga Orang Tertanggung. Jurnal MIPA, 39(1), 70-77.

Suryono, A. (2009). Asuransi Kesehatan Berdasarkan Undang-Undang Nomor 3 Tahun 1992. Jurnal Dinamika Hukum, $9(3), 213-221$.

Wilandari, Y. (2007). Asuransi Kesehatan Individu Perawatan Rumah Sakit. Jurnal Matematika, 10(3), 73-78. 